\title{
CELTO - GALLO - ROMAN STUDIES OF THE MTA-ELTE RESEARCH GROUP FOR INTERDISCIPLINARY ARCHAEOLOGY, EDITED BY L. BORHY, K. DÉVAI, AND K. TANKÓ
}

SZABadváry TAMás

Magyar Régészet 8. évf. (2019), 3. szám, pp. 41-43, https://doi.org/10.36245/mr.2019.3.7

A Szabó Miklós akadémikus által alapitott, 1999 óta müködö MTA-ELTE Interdiszciplináris Régészettudományi Kutatócsoport bel- és külföldi kutatási színtéren egyaránt számos, nemzetközi viszonylatban is jelentös tudományos értékü eredményt mutatott fel. A most megjelent tekintélyes tanulmánykötet 20 szerzö 14 cikkét tartalmazza angol (9), francia (3) és német (2) nyelven. A tanulmányok az alábbi témakörök szerint oszlanak meg: az antik Bibracte (Mont Beuvray) francia-magyar régészeti csoport által kivitelezett kutatásai (2); a romanizáció numizmatikai-ikonográfiai vonatkozásai, Kr. e. 1. sz. - Kr. u. 2. sz. (1); Povegliano késö vaskori temetöjének antropológiai értékelése (1); az ókori Brigetio (Komárom-Szöny) területén, az ELTE-BTK Régészettudományi Intézete és a Klapka György Múzeum (Komárom) által szisztematikusan végzett feltárások (polgárváros, légiótábor, canabae, temetők, korábbi ásatások azonositása, anyagi kultúra) és az ehhez köthetö, kiterjedt interdiszciplináris módszerek (antropológia, légi régészet, térinformatika), föként az utóbbi években elért prominens eredményei (9); késö római kori barbaricum (1).

Szabó M., Tímár L. és Szabó D. (11-26) a bibractei („l'îlot des Grandes Forges”) domus és a korábbi periódusban épült basilica szerkezeti és építéstörténeti problematikájára kerestek támpontokat. Legfőbb megállapításuk, hogy a basilica a késő köztársaság idei belső perystiliummal és külső kerengőtérrel rendelkező alaprajzot követi, amelynek kronológiai hátterét a kerámiaanyag is megerősíteni látszik (La

\section{Celto - Gallo - Roman}

Studies of the MTA-ELTE Research Group for Interdisciplinary Archaeology

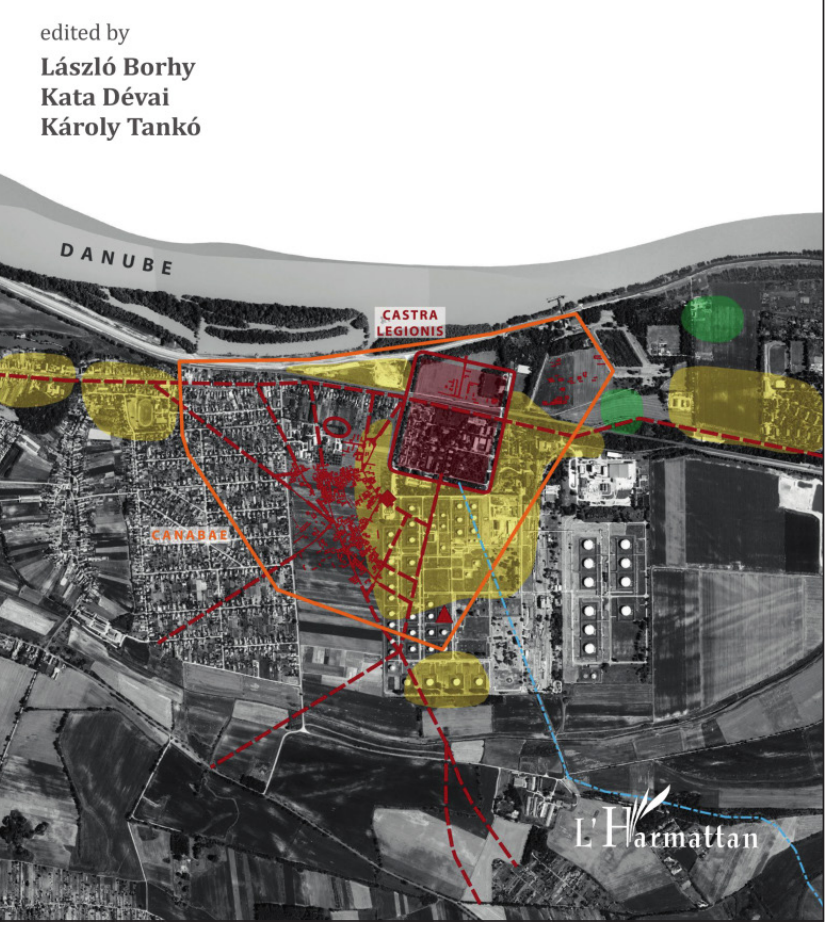

L. Borhy, K. Dévai, K. Tankó (szerk.):

Celto - Gallo-Roman Studies of the MTA-ELTE Research Group for Interdisciplinary Archaeology.

Paris: L'Harmattan, 2018

\section{Keménytábla, 311 oldal, 178 ábra} ISBN 978-2-343-16091-7

Tène D2b - Kr. e. 50/30 k.). Az épület ebből adódóan az épülettípus első régészetileg azonosított példájának tekinthető. Szabó D. (27-34) külön tanulmányban foglalkozik a bibractei basilica kerámiaanyagának összetételével (a 2009/1 szonda leleteire koncentrálva), és megállapítja bizonyos típusok teljes hiányát (terra sigillata, ACO csészék, bordázott peremű korsók), ezáltal is támogatva a basilica Augustus-kor előtti építését. Bózsing É. (35-44) Povegliano Ortaia késő vaskori temetőjében feltárt, tizenhárom, többszörös hamvasztásos temetkezés antropológiai elemzését végezte el. A sírokban felnőttekhez és gyermekekhez tartozó kalcinált csontok voltak megfigyelhetőek. Jól elkülönülnek azok az esetek, ahol a halottakat egyszerre (kevert csontanyag, azonos égetési hőfok), illetve külön-külön (egy-egy személyhez köthető csontanyag, változó égetési hőfok) hamvasztották el. Juhász L. (45-62) a római éremverés példáinak felhasználásával 
mutatott rá a romanizáció ikonográfiai szempontból elemezhető kérdéseire. A tanulmány föként Gallia, Hispania és Dacia tartományok megjelenítésére és attribútumaira összpontosítva értékeli az eszköztár alakulását, melynek változásához a belső küzdelmek is erősen hozzájárultak. Bartus D., Borhy L., Sey N. és Számadó E. a Brigetio területén, 2012-2016 között végzett feltárások eredményeit összegezték. SzőnyVásártéren kiemelkedő felfedezésnek minősült a 2012-ben napvilágra került (2.) pince, melyben kiváló állapotban örződtek meg a plafont (egyben a felette elhelyezkedő helyiség padlóját) képező fa deszkapalánkok. A gazdag leletanyagból kiemelendő egy „L PVBLIC” bélyeges üvegedény, egy bronz lovassági díszsisak, valamint egy olívaolaj szállítására szolgáló amphora (Dress. 20). 2014 nyarán mentő feltárásra került sor Brigetio eddig szisztematikusan nem kutatott canabaejának területén. Az ásatás nyugati zónájában egy, a II. század végétől egészen a késő római időszakig müködő, terrazzo padlóval burkolt (valamint vélhetőleg festéssel díszített), hypocaustum-rendszerrel és két, eltérő periódusban használt praefurniummal ellátott, fürdőépületként interpretált építmény került a felszínre. 2015-ben, a fürdőtől keletre fekvő felületen egy nagy kiterjedésü, masszív falakkal épített horreum alaprajza bontakozott ki, mely mellett egy kisebb, szögletes objektumot is sikerült megfigyelni (valószínúleg ugyancsak horreum lehetett); a leletanyag sorából kiemelkedik Vespasianus aureusua. További kutatások folytak 2015-ben a brigetioi táborban (Komárom-Szőny-MOL-Kiskertek), ahol az előző évben fémkeresős tevékenység során (keleti felület) megtalálták I. Philippus Arabs bronz törvénytáblájának töredékeit. Meglepetésre ugyanitt egy újabb, a tábla alsó feléhez illeszkedő darab került elő késő római kori rétegből. Sikerült azonosítani továbbá egy északdéli irányú útvonalat, melyet a Severus-dinasztia idején kőlapokkal burkoltak, ennek a keleti oldalán futó szennyvízcsatornából egy bronz groteszk fejet ábrázoló kocsi alkatrész látott napvilágot. A principia feltételezett zónájában két felületet nyitottak meg, ahol egy udvar 5 periódusban használt rétegei bontakoztak ki. Rupnik L., Czajlik Z. és Bartus D. (83-96) a Brigetio térségében végzett komplex légi régészeti, műszeres és térinformatikai vizsgálatok elmúlt években elért eredményeit összegezték. A kutatás kiegészült a ma már szélesebb körben elérhető archív légi felvételek felhasználásával, melyek segítségével a jelenleg már nem kutatható térségek is beilleszthetővé válhatnak a modern ismeretanyagba. A kötet legterjedelmesebb tanulmányát Borhy L., Dévai K., Bózsa A. és Számadó E. (97-186) hiánypótló feldolgozása képezi Brigetio polgárvárosának ún. nyugati temetőjéről. A 2009-2010-ben végzett feltárások (Komárom-Lidl szupermarket) 87 sírt eredményeztek, melyből 42 bizonyosan hamvasztásos, míg 31 csontvázas temetkezés volt - utóbbiak sorából kiemelendő egy bolygatott szarkofágtemetkezés is. A szerzők a sírleírások mellett részletesen tárgyalják az egyes temetkezési formákat, továbbá tárgytípusok szerint értékelik az 1-2. századra keltezhető mellékleteket (unikális jelentőségű egy elefántcsont írótáblácska és fedeles tégely [40.sír]). A tanulmány részletesen közli az egyes sírrajzokat, felvételeket, valamint táblázatba szerkesztve az egyes mellékletek rajzát és fényképét (Fig.1-51.). Bödőcs A. (187-194) a Komárom-Lidl szupermarket területén 2009-ben feltárt (Brigetio ún. nyugati temetője), túlnyomóan kora császárkori temetőrészlet szerkezetének értékelését közölte. Bár bizonyos esetekben a felületek dokumentálásra alkalmatlanok voltak, ennek ellenére három csoport volt elkülöníthető a tájolás és a kiterjedés alapján. Ezek legközelebbi párhuzamai NemesbődCserpregi-völgyre-dülő II (Vas m.) sírmezőjén találhatóak meg. A két előbbi tanulmányt kiegészítve Merczi M. (195-214) végezte el a Komárom-Lidl területén megismert temetőrészlet antropológiai vizsgálatát. A 31 kora- és 3 késő császárkori sír csontanyaga általánosan rossz fenntartást mutat, a koponyaméret szerinti értékelés alapján nincs különbség más Észak-Kelet-pannoniai temetökhöz képest. A bolygatott szarkofágtemetkezés halottjai feltehetően egy 12-14 éves lány, egy kistermetü felnőtt, valamint egy nagyobb termetü nő (maturus) maradványai lehettek. Simon B. (215-222), Bíró E. 1970-ben végzett brigetioi ásatásának lokalizálására (Komárom-Szőny-Vásártér-élelmiszer áruház) tett kísérletet. A feltárt objektum bizonyos fokig eltér a jelenleg ismert, térinformatikai módszerrel (és archív légi felvétellel) felvetített állapottól, további elörelépést a kérdéses zóna tényleges feltárása, illetve magnetométeres vizsgálata hozhatna. Sey N. (223-242) 152 katalógustételben mutatja be a brigetioi légiós tábor területére lokalizálható csont-, és a 2014-ben, a canabaeban (Szőny-Dunapart) felfedezett fürdőtől keletre eső bronz öntőmühely leletanyagát. A csontanyagban kiemelendő egy elefántcsontból vagy elefántagyarból faragott korong (Cat. 21.). Kis Z. (243-258) a Brigetioban talált vékonyfalú, rárakott (barbotin) díszes kerámiaanyagot gyüjtötte össze (27 
tételt számláló katalógussal). A rajtuk található, zömében növényi díszítéseket elemezve 14 eltérő variációt talált. Sáró Cs. (259-280) 19 Komárom-Esztergom megyei lelöhelyü sírkövet katalogizált, melyeken a „,bennszülött” nöi viseleti elemek voltak megfigyelhetőek. A fibulák sorában több esetben a régészeti leletanyaggal párhuzamba állítható, típuson belüli formai különbségeket is regisztrálni lehet (noricumipannoniai szárnyas fibula). A korábbi kutatás által hangsúlyozott „bennszülött” jelleg terminológiai behatárolása kiegészítésre szorul, mivel az egyes viseleti elemek nem pusztán a helyi körből kerülnek ki (csuklós szerkezetü fibulatípusok), továbbá területi elterjedésük sem szükíthető az adott területre. Soós E. és Tankó K. (281-301) a késő római kori (C3) barbaricumba eső Pásztó-Csontfalva (Nógrád m.) Zagyva-völgyben elterülő germán jellegü településén végzett feltárást (2005) értékelték. A szükebb tájegységben gyakorlatilag egyedüliként megismert telep szerkezete illeszkedik a germán környezetbe, azonban a leletanyag (kézzel formált és korongon készült, díszítés nélküli kerámia) eltérö jellegzetességeket mutat - az eltérések értelmezésére a térség kiterjedtebb vizsgálata fog választ adni. 